\title{
Episteme
}

http://journals.cambridge.org/EPI

Additional services for Episteme:

Email alerts: Click here

Subscriptions: Click here

Commercial reprints: Click here

Terms of use : Click here

\section{EPISTEMIC INJUSTICE IN THE SPACE OF REASONS}

Matthew Congdon

Episteme / Volume 12 / Issue 01 / March 2015, pp 75 - 93

DOI: 10.1017/epi.2014.34, Published online: 02 February 2015

Link to this article: http://journals.cambridge.org/abstract S1742360014000343

How to cite this article:

Matthew Congdon (2015). EPISTEMIC INJUSTICE IN THE SPACE OF REASONS.

Episteme, 12, pp 75-93 doi:10.1017/epi.2014.34

Request Permissions : Click here 


\title{
EPISTEMIC INJUSTICE IN THE SPACE OF REASONS
}

\author{
MATTHEW CONGDON
}

matthew.congdon@vanderbilt.edu

\begin{abstract}
In this paper, I make explicit some implicit commitments to realism and conceptualism in recent work in social epistemology exemplified by Miranda Fricker and Charles Mills. I offer a survey of recent writings at the intersection of social epistemology, feminism, and critical race theory, showing that commitments to realism and conceptualism are at once implied yet undertheorized in the existing literature. I go on to offer an explicit defense of these commitments by drawing from the epistemological framework of John McDowell, demonstrating the relevance of the metaphor of the "space of reasons" for theorizing and criticizing instances of epistemic injustice. I then point out how McDowell's own view requires expansion and revision in light of Mills' concept of "epistemologies of ignorance." I conclude that, when their strengths are used to make up for each others' weaknesses, Mills and McDowell's positions mutually reinforce one another, producing a powerful model for theorizing instances of systematic ignorance and false belief.
\end{abstract}

\section{INTRODUCTION}

In this paper, I critically examine some trends in recent social epistemology concerning the entanglement of unjust social formations and epistemic practice, exemplified by Miranda Fricker's concept of 'epistemic injustice' and Charles Mills' concept of 'epistemologies of ignorance'. The purpose of my examination is twofold: (i) to reveal some implicit theoretical commitments to versions of realism and conceptualism at work in this strand of thought; (ii) to offer a defense of these commitments towards the end of defending a critical social epistemology.

In section 2, I offer a survey of the critical strand of social epistemology I have in mind, with the aim of drawing out consistent yet undertheorized commitments to realism and conceptualism in that body of literature. I show that although these commitments are relied upon and, at times, explicitly avowed, a thoroughgoing defense is lacking. In sections 3 through 5 , I borrow some insights from John McDowell to build up a conception of the 'space of reasons' that can accommodate these twin commitments. In section 6, I return to the work of Mills, showing how McDowell's conception of the space of reasons requires critical revision to account for cases of structural ignorance and false belief. I conclude that McDowell and Mills' positions reinforce one another, producing a powerful model for theorizing epistemic injustice. 


\section{REALISM AND CONCEPTUALISM IN CRITICAL SOCIAL EPISTEMOLOGY}

While the insight that our epistemic practices are socially conditioned is not new, ${ }^{\mathrm{I}}$ recent work in what we could call critical social epistemology - exemplified by Charles Mills, Linda Martín Alcoff, José Medina, and Miranda Fricker - is distinguished by its focus on epistemic practices that undergird unjust social formations through the systematic production of ignorance and false belief. ${ }^{2}$ Critical social epistemology offers analyses of unjust social formations by approaching them at a distinctly epistemological level, focusing on ways in which certain forms of knowledge are excluded from public exchange, and how the epistemic authority of certain would-be knowers is either denied or diminished, not simply as the result of contingent epistemic failures, but in ways structurally connected with unjust conditions themselves. ${ }^{3}$ Such analyses have resulted in the demarcation of several analytically distinct forms of "epistemic injustice." In Epistemic Injustice, Fricker (2007) diagnoses cases of "testimonial injustice," unfair deflations of one's epistemic credentials on the basis of identity prejudice, and "hermeneutical injustice," unfair differential access to interpretive resources appropriate for one's social experience. While Fricker focuses on ways in which a discriminated-against group is marginalized from full epistemic participation, Mills (1997, I998, 2007) has attempted to reveal epistemic injustice working in the opposite direction, focusing on how those benefitting from oppression maintain forms of ignorance and false belief in themselves in order to sustain oppressive practices, an epistemic phenomenon he refers to as an "epistemology of ignorance" (Mills I 997: I8). Mills argues that certain race-based forms of ignorance and false belief persist because, though cognitively dysfunctional, they play roles that are psychologically and socially functional. For example, the representation of Native Americans as stateless savages living in an undeveloped wilderness, though cognitively dysfunctional given its divergence from the reality of a people with established forms of government and agriculture, nonetheless played a socially functional role in the classical period of European expansionism as a conceptual tool for justifying imperialism (Mills 2007: 26-7). The myth of the savage is a socially functional cognitive dysfunction, getting reality wrong while nonetheless shaping reality, a combination placing Mills' idea of an

I For instance, we find consistent recognition of the social conditioning of epistemic practices in Aristotle (1984). The clearest example of this recognition is his insistence on the habituated nature of the intellectual virtues, which require an ethical upbringing for their development (Nicomachean Ethics, Book VI). He also consistently notes the relevance of social class distinctions for the development of different forms of knowledge. See, e.g., his statement in Metaphysics, Book I, 98 I bI 3-24 that mathematics arose in Egypt as a result of the leisure time afforded to the priestly caste.

2 An already classic reference is Mills' The Racial Contract (I997), where the important notions of "epistemologies of ignorance" and "inverted epistemology" are introduced as part of an account of race-based forms of epistemic injustice. Mills expands on the social epistemological themes of The Racial Contract in Mills (I998, 2007). The essays collected in Sullivan and Tuana's Race and Epistemologies of Ignorance (2007) provide a good overview of social epistemology from the perspective of critical race theory. See in particular Alcoff (2007) and Spelman (2007). Miranda Fricker's Epistemic Injustice: Power and the Ethics of Knowing (2007) has also become an essential reference in critical social epistemology. For critical discussions of Fricker's book, see the book symposia in Ibarra (2008), Goldman (20IO) and Bohman (20II). The most expansive work to date on this topic, which critically synthesizes the approaches of Mills, Alcoff, Fricker, and many others is Medina (20I3).

3 For a helpful overview of the evolution of contemporary social epistemology to this point, by way of nineteenth-century Marxism and Quine, see Mills (2007: 13-17). 
"epistemology of ignorance" in line with classic conceptions of ideology. 4 The successor to the myth of the savage in contemporary society is, on Mills' analysis, the ideology of colorblindness, the formal attribution of equality to all while denying the need to address persistent inequalities afflicting present society by the injustices of the past, e.g., slavery and Jim Crow (Mills 2007: 28). The critical thrust of this strand of social epistemology arises from its attempt to diagnose these constructions of ignorance and false belief as substantively nourished by the very unjust social formations they work to hide from view. "Testimonial injustice," "hermeneutical injustice," and "epistemologies of ignorance" constitute the beginning of a typology of general forms of epistemic injustice that critical social epistemology attempts to lay bare. ${ }^{5}$

A striking feature consistently recurring in critical social epistemology is a commitment to a robust form of realism (Mills I997: I 8 and I29; Alcoff, 2007: 55-7; Fricker 2007: 3; Mills 2007: I 5). ${ }^{6}$ Mills points out that the very idea of diagnosing some epistemic practice as systematically encouraging ignorance and false belief relies conceptually upon a contrasting conception of knowledge, a contrast lost, he writes, "if all claims to truth were equally spurious, or just a matter of competing discourses” (Mills 2007: I 5 ). To do its critical work, Mills' position "lays claim to truth, objectivity, realism, the description of the world as it actually is" (Mills I997: I29). Mills' realism is signaled negatively via the rejection of a "postmodernist" alternative, construed as a hopeless form of epistemic and moral relativism. 7 Similarly, Alcoff recommends a postpositivist return to a notion of "objective reason," cautioning against "postmodern refusals of reference, reason, or truth" (Alcoff 2007: 57). Notably, in spelling out their realist commitments, both Mills and Alcoff favor what we could call a "wide" conception of objectivity, one that does not rely on complete abstraction from an embedded subjective standpoint in the way some standard "narrow" conceptions of objectivity do. ${ }^{8}$ Alcoff urges a notion

4 Mills says that The Racial Contract should be viewed "in the spirit of a racially-informed Ideologiekritik" (Mills I997: I29). In this spirit, Alcoff draws connections between Mills and the Frankfurt School. Just as the myth of the savage is cognitively dysfunctional as an anthropological conception yet socially functional within the narrow context of imperialism, critical theorists like Horkheimer and Adorno diagnose modern instrumental reason as "a dysfunctional cognitive norm, functional within very narrow parameters of capital accumulation and the maintenance of ideology but dysfunctional as a reliable, truth-seeking practice" (Alcoff 2007: 50). For two contemporary discussions of ideology as a socially functional cognitive dysfunction, see Haslanger (20I2) and Jaeggi (2009).

5 The typology of forms of epistemic injustice has been subject to some debate. One site of dispute has centered around the relation between "hermeneutical injustice" and "epistemologies of ignorance." See, in particular, Mason (20II), Pohlhaus (20I2), and Medina (20I3). Here I follow Fricker (2013), who suggests that "hermeneutical injustice" and "epistemologies of ignorance" are best viewed as analytically distinct forms of epistemic injustice, even if they often overlap and reinforce one another in actual practice.

6 Medina prefers labels like "polyphonic contextualism" and "pluralism" over "realism," yet nonetheless defends a qualified conception of objectivity over relativist alternatives in Medina (20I3: ch. 6).

7 Mills does not cite any specific advocates of the postmodernist view he wants to reject, leaving the label anonymous. A potential candidate is Wendy Brown's championing of a postmodernist approach to feminism. See, in particular, Brown (1995), where she urges that though women's experiences may be voiced as part of a feminist politics, those voices “cannot be anointed as 'authentic' or 'true' since the experience they announce is linguistically contained, socially constructed, discursively mediated, and never just individually 'had'" (p. 4I).

8 I borrow the contrast between "wider" and "narrower conceptions of objectivity" from Crary (2006: I8-I9). For a related defense of a wider conception of objectivity, see McDowell (I998c). 
of objective reason that makes reference not only to what is actual but also to what is possible within actuality. Being objective involves not only getting things right about social reality, but also about how we might alter social reality, suggesting that what "is" now and what "ought" to be are not neatly separated within her wider conception of objectivity (Alcoff 2007: 53). In the same spirit, Mills makes clear that the notion of realism required by a critical social epistemology must be particularly inclusive, as the forms of ignorance to be diagnosed concern not only matters of fact narrowly construed, but also forms of distinctly moral knowledge. He writes that the kinds of race-based ignorance concerning him are "not merely ignorance of facts with moral implications but moral nonknowings, incorrect judgments about the rights and wrongs of moral situations themselves" (Mills 2007: 22). We find a similar commitment to realism about moral value at work in Fricker's analysis of the hermeneutical injustice of conditions lacking the critical concept "sexual harassment," where what is at stake in voicing one's experience of harassment is not simply that some value-neutral set of events has taken place, but moreover, that the events in question are morally repugnant (Fricker 2007: ch. 7; cf. Fricker 2010: I68-9). So, we consistently find in critical social epistemology a commitment to realism in this wide sense that includes moral truth.

Alongside his commitment to realism, Mills adopts the Sellarsian rejection of a "raw perceptual 'given,' completely unmediated by concepts” (Mills 2007: 24). For Mills, embracing the view that even low-level, pre-reflective perceptual engagements with the world are always already conceptually mediated allows us to appreciate the deep ways in which race-based prejudice can embed itself in our thinking, distorting even basic instances of empirical claim-making, memory, and belief-formation. As Mills elaborates the point, "Perceptions are in general simultaneously conceptions, if only at a very low level" (Mills 2007: 24). Here, Mills is embracing conceptualism, the view that all rational activity, from intentional action and higher-order reflection all the way down to passive perceptual engagements, is mediated by concepts. Like his commitment to realism, this commitment to conceptualism in critical social epistemology is not unique to Mills (see, e.g., Fricker 2007: 67).

However, simultaneous commitments to conceptualism and realism are notoriously difficult to hold together, and a defense of this dual commitment has not been sufficiently addressed within the context of critical social epistemology. In Mills' work in particular, the commitment to epistemic and moral realism is never given a positive defense. ${ }^{9}$ Realism is only announced in a few places as the necessary alternative to the failures of postmodernism: any position that refuses to make use of terms like truth and objectivity will lack the critical tools to diagnose some epistemic practice as systematically productive of ignorance and false belief. This much seems absolutely right, but the mere rejection of postmodernism tells us nothing about the realism we should take up in its stead. Worse, at times he employs the language of scheme-content dualism to advance his conception of the way a realist form of critique might work, as when he writes, "the conceptual array with which the cognizer approaches the world needs itself to be scrutinized for its adequacy to the world, for how well it maps the reality it claims to be describing” (Mills 2007: 24). As

9 The most sustained discussion I know in Mills' work on this issue occurs in Mills (I998: 24-32), where he argues for the compatibility of beliefs being at once based on evidence and tied to a particular social standpoint. However, his discussion there does not explicitly raise the question of whether this entitles us to a "realist" perspective. 
I will discuss below, such suggestions are at best misleading and at worst incoherent given the contrast drawn between the order of the conceptual and the order of the real. ${ }^{\text {I0 }}$ The contrast is, moreover, internally inconsistent with Mills' own avowal of conceptualism, the view that minded engagement with reality is exhaustively conceptual.

The theoretical underpinnings of a critical social epistemology that is at once conceptualist and realist thus need to be made explicit. I approach this problem by bringing critical social epistemology into conversation with another important trend in contemporary epistemology exemplified by McDowell. The Sellarsian image of the "space of reasons" McDowell draws upon is emphatically social, recognizing the ways in which social embeddedness invariably conditions epistemic practices while preserving the idea that the knowledge comprising this space can be credited as objective. Moreover, McDowell defends a conception of objectivity wide enough to accommodate the idea of moral knowledge in a way that matches Mills' realist aspirations. However, McDowell's position is also limited, notably by a lack of attention paid to precisely the questions of injustice that are the central preoccupation of critical social epistemology. Hence, after drawing resources from McDowell to strengthen Mills' position, I continue their engagement by critically bringing Mills' work to bear on McDowell.

\section{IDEAL OR NON-IDEAL?}

Sellars introduces the phrase, "the logical space of reasons" in his famous essay, "Empiricism and the Philosophy of Mind," as part of a discussion of the inherently normative character of knowledge. There, he says, "in characterizing an episode or state as that of knowing, we are not giving an empirical description of that episode or state; we are placing it in the logical space of reasons, of justifying and being able to justify what one says" (Sellars 1997: $\$ 36$ ). That is, in referring to some episode or state as an instance of knowledge, we are ascribing to it a particular kind of normative authority, namely, that it can be legitimately employed in practices of epistemic justification. The space of reasons refers to this space of normative authority, to that network of norms governing what counts as a reason for what, what counts as an instance of knowing, and who counts as a knower.

In order to home in on the form of objectivity we need, it will be helpful to distinguish between ideal and non-ideal versions of the space of reasons, defending the latter over the former. We can take as an example of the former a view put forward by Peter Railton (I997) as part of a defense of his brand of moral realism. He offers us an idealization procedure that can be performed on any individual $A$ to arrive at a formal conception of A's “objective interests." One's objective interests are not merely one's arbitrary subjective preferences, but rather indicate what one has objective reason to do. We can arrive at $A$ 's objective interests by adding to the concrete individual $A$ "unqualified cognitive and imaginative powers, and full factual and nomological information about his physical and psychological constitution, capacities, circumstances, history, and so on” (Railton I997:

Io Criticisms of scheme-content dualism extend at least from Hegel to contemporary epistemology (see, e.g., Davidson 1974; McDowell I996; Hegel I977: Introduction). More directly with regard to Mills, it is on the grounds of such a dualism that Harvey Cormier (2007) levels his criticisms of the idea of an "epistemology of ignorance." 
I42). This addition yields " $A+$," an idealized version of $A$ who enjoys complete and vivid knowledge of herself, the world, and flawlessly functioning rational faculties. If we ask $A+$ what she would want her non-idealized self to want or seek, given $A$ 's actual condition, the answer $A+$ gives will yield $A$ 's objective interests, i.e., what $A$ has objective reason to pursue, irrespective of her actual, potentially flawed, and merely subjective interests. The possibility of $A$ 's maturation into a competent agent is underwritten by feedback mechanisms contributing to a process of practical learning: through experience, $A$ 's subjective interests may gradually come to approximate $A+$ 's interests, at least in a partial fashion.

Railton employs the same idealization procedure to arrive at a conception of objective moral reasons, with the difference that the interests in question are taken to be that of a social group as a whole (Railton 1997: 150). The assumption of "full and vivid information" provides the same kind of idealization that generated the idealized individual, $A+$, this time considering the objective good of all involved. So what is objectively morally good in a given situation is whatever would be collectively adopted as the best course of action by a democratically organized group of “ $A+$ ” versions of ourselves deliberating over how best to navigate our non-idealized condition.

Why isn't the space of reasons not like this? Why not interpret the rational requirements comprising that space as "there in any case" in the sense that they would be recognized as the right reasons if we had full and vivid knowledge of ourselves and our world? Indeed, McDowell's own formulation of the rational requirements comprising "the ethical" may invite precisely this kind of reading. ${ }^{\text {I I }}$ Though the terms would depart from Railton's vocabulary, the logic of idealization in the case of the space of reasons would be the same: take some actual moral agent, add to her a repertoire of conceptual capacities admitting no significant lack, and the reasons to which she is responsive can be understood as the objective reasons of the actual moral agent, whether or not she is actually responsive to those reasons. From there, the space of reasons could be formally defined as the totality of such objective reasons. "Epistemologies of ignorance" could be understood as systematically obscuring this space of objective reasons, and criticized on the latter's basis.

It is tempting to interpret the space of reasons this way because it offers a simple model for thinking about the existence of reasons responsive to our particular needs, yet which may transcend the set of reasons we are presently in a position to grasp. Moreover, the idealized picture seems to translate well into cases of epistemic injustice. When we give a retrospective account of a moral wrong prior to the discursive shift allowing us to articulate that wrong explicitly, as in the case of sexual harassment prior to the development of the term "sexual harassment" in the mid-seventies, we want to say that justifications for our taking it to be wrong were part of the space of reasons prior to our collective realization of that fact. And one way of accounting for their being "there in any case" would be to say they are part of the set of moral reasons we would have recognized if we were idealized versions of ourselves, if we truly and vividly knew ourselves and our world.

We can see what is wrong with this picture by reflecting on a feature Railton does not, namely, the kinds of transformations accompanying $A$ 's gradual learning process concerning what counts as a reason for what, which interests are really desirable and

I I "The ethical is a domain of rational requirements, which are there in any case, whether or not we are responsive to them. We are alerted to these demands by acquiring appropriate conceptual capacities" (McDowell I996: 82). 
valuable. In McDowell's writings this process goes under the heading of Bildung, our gradual emergence into the space of reasons as children through our induction into language and later as adults through reflective refinements of our inherited conceptions of the space of reasons (McDowell I996: 84, 87-8). A's asymptotic approximation of $A+$ is figured in Railton as the acquisition of atomistic bits of knowledge standing there, formed in advance of any transformative process of Bildung. The very idea that $A$ 's objective interests are simply those interests $A+$ would want $A$ to have presupposes no transformation would take place in the very nature of those interests, and hence the reasons they embody, as part of $A$ 's coming to grasp those objective interests and reasons through a process of maturation and learning. This presupposition, however, falsely abstracts the space of reasons from the very process of Bildung that brings us into its midst.

Articulating our interests and the value of our interests (by developing, for instance, new moral categories like "sexual harassment") is not like merely designative forms of predication, which take certain properties as independent of one's articulating them (Taylor I985b: 218-19). Rather, as Charles Taylor puts the point, "articulations are attempts to formulate what is initially inchoate, or confused, or badly formulated. But this kind of formation or reformulation does not leave its object unchanged. To give a certain articulation is to shape our sense of what we desire or what we hold important in a certain way" (Taylor I985a: 36). Articulation follows an expressive logic, meaning that what it expresses is not something wholly determined in advance of the expression, but rather comes to be what it is at least partially as the result of expression. The subject of self-interpretation is simultaneously the object of interpretation, and so we can refer to a "subject-object" of self-interpretation. Insofar as the subject-object of self-interpretation is undergoing the activity of self-interpretation, it is not static but rather undergoing a change via that very process.

Take, for example, two friends attempting to articulate the meaning and value of their friendship after a fight. Insofar as their sitting together to articulate their friendship is itself a significant event in the history of the very friendship being interpreted, their acts of selfinterpretation will not leave the object unchanged. Rather, the act of articulating the friendship is part of what the friendship is becoming. In this kind of evolving, selfreferential case, it makes no sense to say our objective interests concerning our friendship are those interests held by "I-plus" and "you-plus" versions of ourselves in advance of any concrete efforts on the part of our non-ideal selves to come to a genuine understanding of the meaning of our situation. This is fully consistent with the idea that our articulations concerning the nature of the object can range from the discerning to the deluded and so, even as the object evolves, there is a meaningful sense in which we can speak of being objective about the matter at hand.

We can see this expressive logic of articulation at work in an exchange between Fricker and Alcoff concerning the effects transformations in language have in conditions of hermeneutical injustice. Hermeneutical injustice occurs when a group is excluded from developing shared interpretive resources, and so is put at an unfair disadvantage in making sense of experiences important to that group. In developing this concept, Fricker is concerned with the possibility of our existing discursive resources preempting someone's speaking the truth about one's social situation, say, that one has been sexually harassed. Taking off from Fricker's metaphorical assertion that hermeneutical lacunas are like "holes in the ozone" (Fricker 2007: I6I), ${ }^{\mathrm{I2}}$ Alcoff says she "wonders if this implies a realist account of meaning as reference to already existing, fully formed objects, objects 
existing, like global warming, whether they are acknowledged by this season's political administration or not" (Alcoff 20I0: I36). Against this strong realist view, Alcoff suggests an alternative echoing precisely the concept of articulation:

[O]ur ability to name experiences can in some cases change their shape and their affective texture. Consider again the case of sexual harassment, in which the term we use to classify the experience changes it from amorphous or generic aggravation to a specific and remediable injustice, or from 'women's lot in life' to communally sanctioned harm. There is a rather sensitive relationship between the way life appears and feels, and the conceptual repertoire we have available to us to describe it. And changes in the terms by which we bring experiences under a description can affect the actual things themselves - especially in so far as these are experiences - that are referred to by the terms. (Alcoff 2010: I36)

In her response, Fricker agrees with Alcoff's suggestion, clarifying her view by suggesting a form of realism that can accommodate the transformative effects articulation may have on its object. According to this more sophisticated realism, we can insist upon the reality of someone's having been sexually harassed prior to the development of the critical concept, "sexual harassment," insofar as the resources for constructing that concept are "immanent in our collective hermeneutical resources" (Fricker 2010: I68). By this she means that the availability of a web of related and already developed concepts and norms - burgeoning notions of sexism, discrimination, non-sexual forms of harassment, etc. - allow an experience to come forth as meaningful in ways that reflects one's objective condition even if it cannot be given the precise label, "sexual harassment." In this sense, she says, she is happy to be called a "realist" about social phenomena, for "it is entirely possible to have experiences whose content is shaped by meanings that we are not yet (individually or collectively) able to make explicit in sharply focused reflections or communicative exchanges" (Fricker 20I0: I68). Though at first glance Alcoff's insistence on the transformative effects of naming something might appear incongruous with Fricker's realism, deeper consideration shows them to be compatible. In light of the expressive logic of articulation, it should seem natural that a single view can simultaneously accommodate the transformative nature of articulation and a realist sensitivity to something we can neither master nor will away through articulation.

Acts of self-interpretation, individual or collective, are attempts to articulate some corner of the space of reasons that has to do with who we are. In these kinds of self-referential cases, the space of reasons is transformed by our very efforts to articulate it. Yet it would be a non sequitur to move from this expressive thesis to the further claim that our commitment to realism ought to be jettisoned. That the layout of the space of reasons evolves alongside our efforts to articulate it in no way contradicts the realist claim that there exist objective reasons that are not simply the constructions of subjective spontaneity. We avoid this contradiction as long as we are able to distinguish between (i) the expressive idea that our efforts of articulation have transformative effects upon an objective space of reasons within which knowers are embedded and (ii) the anti-realist idea that our efforts of

I The metaphor takes place in the context of a discussion of the fact that hermeneutical injustice, though affecting the vocabularies and discursive styles of an entire linguistic community, disproportionately affects certain marginalized groups rather than others: "Hermeneutical lacunas are like holes in the ozone - it's the people who live under them that get burned. Fundamentally, then, hermeneutical injustice is a kind of structural discrimination" (p. I6I). 
articulation are the exhaustive source of a subjectively constructed space of reasons. The former sits well with the realist premise that our efforts of articulation aspire to be rationally responsive to the way things are, so long as we keep in mind the expressive point that "the way things are" may be transformed by human activity, including the human activity of articulation. The argument I have offered here, and the position Fricker embraces in her response to Alcoff, lead us to this expressive realism. Hence, we can remain realists about the existence of social phenomena like sexual harassment while taking on board Alcoff's point that newly developed conceptual capacities like "sexual harassment" can have deeply transformative effects upon those very phenomena.

The idealized variation of the space of reasons is, ultimately, self-defeating, since it treats objective reasons as static, as if unaffected by our transformative efforts to grasp and make use of those reasons. This means that whatever we mean by the "space of reasons," we can be referring to nothing other than our actual, non-idealized world insofar as it is rationally and ethically meaningful.

\section{SOCIAL RATIONALISM OR NON-TRADITIONAL EMPIRICISM?}

I now want to consider two different non-ideal readings of the space of reasons, so we may continue to home in on the version of the metaphor best suiting critical social epistemology. On the one hand is a view we can refer to as social rationalism, defended by Robert Brandom, which depicts the content of the space of reasons as exhaustively determined by socially instituted practices of justification and warrant (Brandom I994, 2000). On this view, the world only bears normative authority over thought and action insofar as we grant it that authority as an expression of normative commitments we give to ourselves. On the other hand is a view of the space of reasons as amenable to a non-traditional empiricism, as McDowell puts it. ${ }^{\mathrm{I} 3}$ On this view, normative authority in general - from epistemic authority to moral authority - inheres in the world of objects and situations, such that part of what it means to describe empirically some feature of the world already involves, internal to that description, an appreciation of its normative significance. This allows room for the idea that we may have empirical grounds for "warping a prior conception of the topography of intelligibility" (McDowell I996: I87).

It can seem difficult to give an empiricist reading of the space of reasons, given that Sellars introduces the metaphor by way of a contrast with empirical description. ${ }^{\mathrm{I}}{ }^{4}$ When we characterize something or someone in epistemic terms, as an instance of knowing or as a knower, we are saying something about the kind of normative authority that thing or person has in the context of practices of justification and warrant. Rebecca Kukla helpfully illustrates this point by noting the difference between " $p$ is green" and " $p$ is

I3 This is a theme running throughout McDowell's writings. See, especially, McDowell (I996, 2009b, 2009c). McDowell's ethical writings, many of which center on developing Aristotle's concept of phronesis as a perceptual capacity, are deeply relevant here, as a non-traditional empiricism includes the idea that concrete situations present themselves as already ethically significant, and that we can come to appreciate that significance through experience. See McDowell (I998a, especially essays 2, 3 , and 6).

I " $4 \mathrm{I}] \mathrm{n}$ characterizing an episode or state as that of knowing, we are not giving an empirical description of that episode or state; we are placing it in the logical space of reasons, of justifying and being able to justify what one says" (Sellars I997: $\$ 36$ ). 
evidence" (Kukla 2000: 209-10). The former is an empirical description of $p$, whereas the latter is not simply a claim about some state of affairs, but is a claim about the sort of epistemic authority $p$ has in the context of practices of justification and warrant, a distinctly normative ascription as opposed to an empirical description of $p$. A similar contrast between normative ascription and empirical description seems to hold for persons. Unlike empirical descriptions of persons (e.g., "She has ten fingers"), epistemic characterizations of persons (e.g., "She is a knower") are distinctly normative, making claims about the kinds of authority and responsibility we recognize that person as possessing. Characterizing someone as a knower carries with it normative expectations, e.g., that her statements be supported with reasons and that she may legitimately demand reasons from others for what they say and do. Making an empirical description of someone, say, that she has ten fingers, may be a move within the space of reasons, but it is not, unlike normative ascription, a claim about the layout of the space of reasons. So, placing someone in the space of reasons seems conceptually distinct from giving an empirical description of that person.

If we hold fast to this contrast, we are led fairly naturally towards the social rationalist reading of the space of reasons. According to the contrast, normative authority is not found in the empirical world, and so when we ask about something's epistemic normative status, e.g., "Is $x$ really an instance of knowing?" we will not find confirmation or disconfirmation by looking at the world. This is because normative ascriptions such as " $x$ is an instance of knowing" are not claims about items in the empirical world, but are assertions about what we are permitted and restricted from doing with some episode or state in practices of reason-giving. Statements like " $p$ is evidence" or " $S$ is a knower, capable of offering and receiving reliable testimony" are part of a mapping out of epistemic normative space, an outlining of the permissions and restrictions constituting the norms governing our practices of justification and warrant. These justificatory practices, in turn, are the developed result of acts of collective self-legislation, our collectively taking certain episodes and states to be authoritative, our collectively recognizing persons as knowers capable of testimony, and so forth. And thus we are led towards social rationalism.

Non-traditional empiricism, by contrast, develops a picture of the space of reasons that questions the hard contrast between normative ascription and empirical description. On this view, it is only through a person's embodied, expressive actions that she manifests her status as a knower, so that through material events like speech and writing, as well as postures and facial expressions we view as contemplative, her being a knower is directly perceived. In this sense, we empirically perceive (and misperceive) others as knowers, which is simultaneously to see others as bearing normative authority. We can deepen this by following a line of thought in McDowell's Mind and World, namely that the normative authority we bear as knowers can be understood as located within empirical reality, insofar as our epistemic capacities are part of our being the kinds of animals we are (McDowell I996: lecture IV). Drawing from the concept of second nature, McDowell urges that knowers emerge from yet are irreducible to first nature, such that participating in activities of knowing and reasoning do not bring us outside nature but rather form part of "our own special way of living an animal life" (McDowell I996: 65). Our emergence as rational knowers is guided by the kinds of education (Bildung) that characterize our induction into language and tradition as children. If we take knowing to be second natural in this sense, then to recognize another person as a rational knower just is recognizing her 
as participating in an activity typical of our species. Further, if recognizing someone as a knower is just part of what it means to recognize her as a normally developed example of the kind of animal she is, we are not far from the idea that ascriptions of epistemic fact ("She is a knower") are empirical claims, analogous to the manner in which our recognizing a bird as capable of flight is an empirical claim. ${ }^{15}$ Yet recognizing someone as a knower, although empirical in this sense, continues to carry with it normative expectations. So recognizing someone as a knower is an instance in which empirical description and normative ascription invariably converge.

On this view, experience can disrupt our received conceptions of what or who counts as normatively authoritative. Consider the case of " $S$ is a knower, capable of offering and receiving reliable testimony," transposed into the context of what Fricker calls "testimonial injustice," when prejudice causes a hearer to give a deflated level of credibility to a speaker's word (Fricker 2007: ch. I). In an extreme case, testimonial injustice amounts to one's wrongful displacement from the space of reasons. On the non-traditional empiricist account, we can understand the perpetrator of testimonial injustice as missing certain objective features of the world, namely, those expressive acts manifesting $S$ 's status as an authoritative knower. Insofar as those expressive acts are themselves already normative, we can point to them as justifications when we attempt to criticize such cases of testimonial injustice as, precisely, unjust. While many empirical features of a person may be irrelevant to the question of her epistemic authority (e.g., her having ten fingers), it will also be precisely her epistemic deeds in the empirical world that publicly display her authority and hence performatively contradict the claim that she is not an authoritative knower. In our judgment of such deeds, our attentiveness to her empirical actuality and her normative authority converge, and so our failure to appreciate one is a failure to appreciate the other.

Whereas for social rationalism our socially established epistemic practices exhaustively determine the layout of the space of reasons, for non-traditional empiricism, these inherited schemes are rationally vulnerable to experiential episodes capable of warping the topography of intelligibility. Our childhood acquisition of language is, for McDowell, the primary way in which we make our first steps into the space of reasons. He writes, "In being initiated into a language, a human being is introduced into something that already embodies putatively rational linkages between concepts, putatively constitutive of the layout of the space of reasons, before she comes on the scene" (McDowell I996: I25). He goes on, "[A] natural language, the sort of language into which human beings are first initiated, serves as a repository of tradition, a store of historically accumulated wisdom about what is a reason for what" (p. I26). Language is not simply a tool for communication, or a set of designative terms, but bears in its grammar a socially developed articulation of rational space. To that extent, it bears the imprint of past experiences and reflections upon those experiences, insofar as those experiences and reflections have gone into the gradual, historical shaping of a collectively established topography of the space of reasons.

I5 This is not to rule out that such ascriptions involve a more complex logic than empirical claims not targeting living or rational beings. The additional complexity is brought in by the fact that we make such ascriptions of both epistemic fact and animal capacities (e.g., flight) not individualistically but in light of a wider context, namely, the form of life in question. See Michael Thompson (2008) for a discussion of the special turn thought takes when judging forms of life. 
Though this is not McDowell's way of speaking about it, we can put the point in terms of memory. Through the historical development of language we memorialize certain experiences and reflections of previous generations in ways that render them discursively inheritable for the next generation. Language offers to the generation inheriting it a standing set of purportedly rational relations that serves as one's initial orientation in the space of reasons in early childhood. This is, at the very least, a double-edged sword. In an optimistic mood we can say with McDowell that language, insofar as it memorializes the experiences and reflections of past generations, embodies "a store of historically accumulated wisdom of what counts as a reason for what." In a less optimistic mood, or perhaps a realistic one, we will say that the fact that our initial orientation in the space of reasons is only made possible by our inheritance of a language as it already stands is precisely why epistemologies of ignorance can take such an unshakable hold on us. It is not only the wisdom of past generations that is memorialized in language, but also the folly, the blind spots, the prejudice, the influence of abused power.

McDowell's emphasis on the role of inheriting a language and tradition is thus importantly distinct from the social rationalist's insistence that things and persons only appear as normatively authoritative insofar as they conform to socially established epistemic norms. McDowell urges a conception of the space of reasons that is open to "radical ethical reflection" (McDowell I998d: I 89), specifically in response to experiential episodes that open our eyes to forms of normative authority our received frames cannot presently accommodate without remainder. His only insistence is that radical reflection cannot be taken up from a vantage that positions itself wholly outside any received language or tradition. This rejection of validation from an external standpoint is compatible with the possibility of radical critical reflection, which McDowell illustrates with the famous image of "the mariner repairing his ship while afloat" (McDowell I998b: 36). Following this image, critical reflection upon our inherited conceptions takes place from a position within that very inheritance, altering but not suspending it entirely. In this way, the languages and traditions by which we are inducted into the space of reasons are socially and historically developed yet empirically revisable. This preserves the centrality of the social mediation of knowledge while holding onto the idea of empirical constraints on knowledge.

\section{REALISM AND CONCEPTUALISM}

For Mills, conceptualism helps make sense of the ways conceptual arrays shaped by epistemologies of ignorance - exemplified by the myth of the savage and colorblind ideology achieve far-reaching and persistent, distorting effects at the levels of perception, memory, testimony, and beyond (Mills 2007: 23). Yet Mills is not always consistent in how his conceptualism works, and sometimes he speaks as though he favors a picture according to which our conceptual arrays stand on one side of a gap between our knowing activity and the world we try to know. In one of the more egregious passages along these lines, Mills describes how critical scrutiny of our existing conceptual arrays should be understood: "the conceptual array with which the cognizer approaches the world needs itself to be scrutinized for its adequacy to the world, for how well it maps the reality it claims to be describing" (Mills 2007: 24). The "mapping" image suggests a dualist picture of the way conceptual array and world stand to one another. On this dualist view, we could diagnose some conceptual array as inadequate by demonstrating that it fails to "map" 
accurately the reality it purports to describe. However, if we take seriously Mills' initial claim that even low-level perceptions are conceptually mediated, it will not be the case that we can test the adequacy of a conceptual array by comparing it to how things stand in the world, for our very reference to how things stand will itself require mediation by a conceptual array, which will in turn require critical scrutiny.

From here, some unattractive options arise. The first and least attractive is to admit an infinite regress follows when our picture involves testing the adequacy of the conceptual arrays that are employed in testing our conceptual arrays.

A second option is to avoid the regress by relinquishing the commitment to conceptualism, maintaining that we can check the adequacy of a conceptual array by asking how well it maps non-conceptual reality. Yet, if we relinquish that commitment, Mills' image of mapping forces us to fall back onto a version of a raw, unmediated empirical given. This is not a serious option if we reject, as Mills does, that there is some conceptually unmediated point of access to the world from which epistemic and social critique takes place.

A third option, if we reject the foundationalist appeal to an unmediated given, is to maintain a variation of conceptualism while relinquishing realism. With this move, the idea that conceptual arrays are supposed to "map" faithfully something like reality drops out completely and the regress problem is avoided, for it was only the dualist image of mapping that introduced the problem in the first place. This option will of course be unpalatable to Mills, since it reintroduces precisely the kind of anti-realism he views as an "epistemological and theoretical dead end" (Mills 1997: I29). Nonetheless, it is a familiar strategy. Donald Davidson famously criticizes the dualism of conceptual scheme and empirical content in favor of a "coherentist" view, according to which "nothing can count as a reason for holding a belief except another belief" (Davidson I989: 3 I0), meaning that a particular belief's epistemic status is judged according to how well it coheres with an established body of beliefs. Harvey Cormier (2007) has objected to Mills in precisely this spirit, urging that Mills' appeal to reality as providing a critical foothold against epistemologies of ignorance begs the question, preferring "coherentism" in its place. Yet it is precisely under conditions of systematic ignorance that potentially subversive perceptions, memories, and histories are filtered out as "incoherent" (Mills 2007: 25). The fact that a particular web of beliefs is productive of oppression is not, at least on the face of it, incompatible with the internal coherence of that web, and so a coherence theory of truth and knowledge will not provide the kind of critical force needed to diagnose epistemologies of ignorance.

Reconciling realism and conceptualism allows us to avoid these unsatisfactory options. McDowell (I996) suggests their reconciliation as a way of avoiding "the Myth of the Given," the view that conceptual activity is grounded in non-conceptual contact with the world. The problem with the Myth is that non-conceptual episodes, such as causal impacts upon my body, cannot serve as reasons (as opposed to mere exculpations) for holding a belief. The very availability to rational thought of some state or episode depends upon its being, in principle, conceptually discernible, i.e., something that can be picked out of the perceptual manifold as an intentional object of awareness. For some episode or state to be non-conceptual in these terms is for it to be essentially lacking the minimal form allowing a rational being to apprehend it as determinate. But if that is what something's being non-conceptual involves, its being non-conceptual entails its in principle unavailability to the discernment of thought. Hence, a non-conceptual episode or state cannot provide reasons for belief, since non-conceptual content is unavailable to thought. Only 
those episodes and states that are already conceptual provide reasons. Therefore, the rational activity that characterizes the space of reasons, including perceptual experience, is necessarily conceptual all the way down, yet not in any way that threatens the idea of objective purport. For it is precisely by virtue of conceptual mediation that object-oriented thought is possible at all. Realism is not simply reconcilable with conceptualism, but systematically depends upon it.

Though Mills ultimately mishandles his own realist and conceptualist commitments, McDowell's position offers another way to preserve these commitments in a way that fits well with his overall aims. This makes reflective criticism more complicated than the image of "mapping" suggests, yet insofar as it preserves the idea of conceptually mediated yet direct exposure to the authority of objects, it opens up a non-dualist view of objectively grounded critique consistent with Mills' realism.

\section{MCDOWELL'S LIMITATIONS}

I have been building up a conception of the "space of reasons" metaphor with the goal of strengthening undertheorized elements in critical social epistemology as exemplified by Mills. Clearly, however, the line of support needs to run in the other direction as well, and so I conclude by showing how Mills' social epistemology contains insights requiring important revisions to McDowell's conception of the space of reasons.

First, discussions surrounding Sellars and the space of reasons unfortunately fall within what Mills describes as the tendency in contemporary epistemology to remain "blithely indifferent to the possible cognitive consequences of class, racial, or gender situatedness" (Mills 2007: I3). If Mills' broader thesis about the epistemological underpinnings of racial domination are correct, and race-based conceptual arrays account for widespread and systematic forms of cognitive failure throughout history, then mainstream epistemology's recurrent silence about matters of race cannot simply be shrugged off as a failure to omit some particular detail among others, but can be viewed as symptomatic of its own deep entanglement with racial domination. While "space of reasons" epistemology is certainly sufficiently social in character to accommodate in principle the possible cognitive consequences of injustice, there can be no denying that Sellars, McDowell, and those who work within their tradition are predominantly silent on issues of racial, class-, and gender-based injustices as they structure epistemic practice. ${ }^{\mathrm{I}}{ }^{6}$

I know of only one passage in McDowell where such issues are cautiously broached, and even there it is only as part of an argument against the idea that full mutuality of recognition is a necessary precondition for genuinely world-directed thought. He asks, rhetorically,

Are we to suppose that members of downtrodden minorities, say, or those who oppress them, cannot have their empirical thinking rationally controlled by objects they perceive? No doubt restrictions on freedom to act can have effects on freedom of thought. But it would be absurd to claim

I6 There are, of course, some exceptions to this tendency in the literature. See, e.g., Crary (200I), which draws upon the Sellarsian metaphor as part of the argument for "the possibility of a space of reasons which women and men can fruitfully cohabitate" (p. 379). 
that there is no thinking, and hence no involvement of capacities for thought in perceptual experience, unless there is full mutuality of recognition. (McDowell 2009a: 200)17

McDowell's claim here is so minimal - namely, that it would be too much to say that oppressors or oppressed groups completely lack objective thought owing to conditions of oppression - that it is difficult to disagree with his suggestion. Indeed, it would be a caricature of the concept of ideology, or of the idea of an "epistemology of ignorance," to paint it as utterly objectivity-eclipsing. My point in raising this passage is not to contest the thesis it puts forward, but to point out that McDowell's one brief reference to the epistemic conditions of "downtrodden minorities" - especially when considered in the face of the rich contributions of recent critical social epistemology - gestures towards an area that is at once deeply relevant to his own thinking and radically undertheorized.

Secondly, McDowell's conception of language as "a repository of tradition, a store of historically accumulated wisdom about what is a reason for what" requires modification to reflect tradition's simultaneously standing as a store of historically accumulated resistances to genuine knowing, of historically accumulated unwisdom about what is a reason for what. To be sure, McDowell acknowledges this in some brief remarks, for instance when he notes that one's "way of thinking, including its implicit standards for selfscrutiny, may have hitherto unnoticed defects, such as parochialism or reliance on bad prejudice" (McDowell I996: 8I). Nonetheless, like his brief reference to "downtrodden minorities," these are at best vague gestures, and as Mills and others have demonstrated, the complex ways in which various forms of parochialism and bad prejudice infect our epistemic practices, including the ways they are linked to social identity, can be subject to rigorous analysis in their own right. Alcoff helpfully clarifies this point: "Even in mainstream epistemology, the topic of ignorance as a species of bad epistemic practice is not new, but what is new is the idea of explaining ignorance not as a feature of neglectful epistemic practice but as a substantive epistemic practice in itself" (Alcoff 2007: 39). If we incorporate the insights of McDowell and critical social epistemology into one position, we are left with the thought that tradition is simultaneously a store of accumulated wisdom and resistances to knowing what is a reason for what.

Here it is possible to view McDowell and Mills as placing their respective emphases on two sides of the same coin. For McDowell, it is only because our engagements with the world are pervasively conceptual that they can be credited as rational engagements with objective states of affairs. The very idea of conceptually unmediated content leaves us without the resources necessary for that content to play a role in rational thought. Hence, the conceptual mediation of experience is a necessary precondition for object-oriented thought. For Mills, it is only because our engagements with the world are pervasively conceptual that epistemologies of ignorance can get a deep grip on our

I7 The passage requires some context to understand why McDowell would be driven to deny what it is he is denying here. The passage comes in the context of a debate with Robert Pippin over the social versus empirical grounds of epistemic authority. Pippin makes the Hegelian point that mutuality of recognition in a social space is a necessary precondition for object-oriented thought (Pippin 2005: 2I 5). For Pippin, McDowell's idea that empirical thinking is "answerable to the world" is only possible given a prior answerability to one another. McDowell's response is to accept that social answerability and empirical answerability to the world are indeed dialectically entangled, but that the point should not be overstated such that we claim objective purport is only possible under conditions of full mutuality of recognition. 
epistemic lives at the pre-reflective levels of perception and memory. Since our taking the world as intelligible depends upon possessing a conceptual repertoire that is, in large part, a social inheritance not of our own choosing, and since that inheritance takes place in a society structured by relations of dominance and subordination, it follows that our conceptual repertoire is shaped in ways that reflect the interests and experiences of dominating groups (Mills 2007: 24-5; cf. Fricker 2007: ch. 7). If we combine these thoughts, then our inheritance of a conceptual repertoire is simultaneously a condition of possibility of objective thought and a condition of possibility of structural ignorance and false belief. That would seem like a paradox if it were not for the historically evolving and empirically revisable character of our inherited conceptual repertoires, a point on which McDowell and Mills agree.

This is wholly compatible with McDowell's thought yet, once again, undertheorized. We might begin to remedy this lack by developing theoretical categories fitting McDowell's overall picture while placing the needed emphasis on the inherent possibility of epistemologies of ignorance shaping our inherited languages and traditions. For instance, alongside McDowell's frequently used category of "conceptual capacities" we could introduce the notion of "conceptual incapacities." This would refer not simply to a potential yet lacking conceptual capacity in one's conceptual repertoire, but to a substantive locus of false belief and ignorance in one's conceptual repertoire. The myth of the savage, for instance, could be described as involving a network of conceptual incapacities, signaling on the one hand that instances in which the myth is employed in justificatory practices do indeed draw into operation conceptual activity while on the other hand that such conceptual activity is playing the substantive role of blocking a clear view of how things are. With this category we could distinguish between forms of ignorance resulting from our lacking relevant concepts and those resulting from historically developed and socially reinforced conceptual pathologies.

Third, McDowell speaks of our inheritance of "tradition" in the singular, offering the misleading idea that our induction into tradition is an induction into something monolithic. McDowell usually returns to this thought when discussing the possibility of critical reflection upon our inherited conceptual repertoires. For instance, he writes, "Even a thought that transforms a tradition must be rooted in the tradition that it transforms. The speech that expresses it must be able to be intelligibly addressed to people squarely placed within the tradition as it stands" (McDowell I996: I 87). The core thought here is that one cannot achieve a transcendent point of view upon one's own point of view to secure for it either an external validation or external confirmation that some transformation of that point of view is warranted. This thought seems absolutely right. Yet phrasing it in terms of our inability to occupy anything other than a perspective from within a particular tradition, where "tradition" is taken as a singular entity, risks overlooking the possibility that heterogeneous perspectives within a tradition create points of dissonance where critical reflection can get a grip.

This is a deep topic in its own right, and rich discussions already exist in critical social epistemological literature, so here I will just offer one example of the direction this might take with Mills, who favors a "racial version of standpoint theory" (Mills I997: I09; cf. Mills I998). Mills urges the possibility of heterogeneous takes on tradition, even multiple perspectives upon tradition within a single person, through an epistemological development of W.E.B. Du Bois' figure of “double-consciousness." Du Bois writes in The Souls of Black Folk, 
After the Egyptian and the Indian, the Greek and Roman, the Teuton and Mongolian, the Negro is a sort of seventh son, born with a veil, and gifted with a second-sight in this American world, - a world which yields him no true self-consciousness, but only lets him see himself through the revelation of the other world. It is a peculiar sensation, this double-consciousness, this sense of always looking at one's self through the eyes of others, of measuring one's soul by the tape of a world that looks on in amused contempt and pity. (Du Bois I986: 364 )

At least part of what Du Bois is describing here is a sense of epistemic alienation that arises when one is forced to view oneself, measure oneself, by the standards of a world that is not of one's own making, that is of one's oppressors' making. Yet despite the confusion and suffering it may produce, Mills interprets "double-consciousness" as a kind of powerful and potentially critical epistemic achievement, namely, "a critical cognitive distancing" from an inherited conceptual repertoire that both underwrites and is an expression of white supremacy (Mills 2007: I 5). It signals burgeoning alternative conceptual repertoires in critical conflict with mainstream epistemic practices. The critical distancing involved here is not a matter of stepping outside one's tradition to gain an externally validated take on that tradition. Yet it does arise from an internal splitting of tradition, an experiential rupture within received ways of thinking. This warrants a shift in McDowell's manner of speaking about tradition away from monolithic terms. Yet despite his lack of comment on the topic, a revived, race-based form of standpoint theory would be precisely in the spirit of a "non-traditional empiricism" that stresses one's embeddedness in a nonideal world, the inseparability of normative and empirical orders, and the meaningfulness of experiences for which propositional discourse is unprepared. That is, it would be precisely in the spirit of the conception of the space of reasons I have defended here. ${ }^{18}$

\section{REFERENCES}

Alcoff, L. M. 2007. 'Epistemologies of Ignorance: Three Types.' In S. Sullivan \& N. Tuana (eds), Race and Epistemologies of Ignorance, pp. 39-58. Albany, NY: State University of New York Press. 2010. 'Epistemic Identities.' Episteme, 7: I 28-37.

Aristotle. 1984. The Complete Works of Aristotle, J. Barnes (ed.). Princeton, NJ: Princeton University Press.

Bohman, J. (ed.). 20 I I. 'Special Issue: Epistemic Injustice.' Social Epistemology, 25: I45-26I.

Brandom, R. 1994. Making It Explicit: Reasoning, Representing, and Discursive Commitment. Cambridge, MA: Harvard University Press.

- 2000. Articulating Reasons: An Introduction to Inferentialism. Cambridge, MA: Harvard University Press.

Brown, W. 1995. 'Postmodern Exposures, Feminist Hesitations.' In States of Injury: Power and Freedom in Late Modernity, pp. 30-5r. Princeton, NJ: Princeton University Press.

Cormier, H. 2007. 'Ever Not Quite: Unfinished Theories, Unfinished Societies, and Pragmatism.' In S. Sullivan \& N. Tuana (eds), Race and Epistemologies of Ignorance, pp. 59-76. Albany, NY: State University of New York Press.

Crary, A. 200I. 'A Question of Silence: Feminist Theory and Women's Voices.' Philosophy, 76: 37 I-96.

- 2006. Beyond Moral Judgment. Cambridge, MA: Harvard University Press.

Davidson, D. 1974. 'On the Very Idea of a Conceptual Scheme.' Proceedings and Addresses of the American Philosophical Association, 47: 5-20.

I 8 I am deeply indebted to Linda Martín Alcoff, Jay Bernstein, Alice Crary, Karen Ng, and two anonymous reviewers for their criticisms and suggestions on previous versions of this essay. 
_ I989. 'A Coherence Theory of Truth and Knowledge.' In Ernest LePore (ed.), Truth and Interpretation: Perspectives on the Philosophy of Donald Davidson. Oxford: Blackwell.

Du Bois, W. E. B. I986. Writings, N. Huggins (ed.). New York, NY: The Library of America.

Fricker, M. 2007. Epistemic Injustice: Power and the Ethics of Knowing. Oxford: Oxford University Press.

— 2010. 'Replies to Alcoff, Goldberg, and Hookway on Epistemic Injustice.' Episteme, 7: I64-78.

- 2013. 'How is Hermeneutical Injustice Related to 'White Ignorance'?' Social Epistemology Review and Reply Collective, 2: 49-53.

Goldman, A. I. (ed.). 2010. 'Book Symposium: Miranda Fricker's Epistemic Injustice: Power and the Ethics of Knowing.' Episteme, 7: I28-78.

Haslanger, S. 2012. 'Ideology, Generics, and Common Ground.' In Resisting Reality: Social Construction and Social Critique. Oxford: Oxford University Press.

Hegel, G. W. F. I977. Phenomenology of Spirit, A. V. Miller (trans.). Oxford: Oxford University Press.

Ibarra, A. (ed.) 2008. 'Forum on Miranda Fricker's Epistemic Injustice: Power and the Ethics of Knowing.' Theoria, 23: 69-86.

Jaeggi, R. 2009. 'Rethinking Ideology.' In B. de Bruin and C. Zurn (eds), New Waves in Political Philosophy, pp. 63-86. London: Palgrave Macmillan.

Kukla, R. 2000. 'Myth, Memory, and Misrecognition in Sellars' 'Empiricism and the Philosophy of Mind'.' Philosophical Studies, IOI: I6I-2 I I.

Mason, R. 20I I. 'Two Kinds of Unknowing.' Hypatia, 26: 294-307.

McDowell, J. I996. Mind and World. Cambridge, MA: Harvard University Press.

— I998a. Mind, Value, and Reality. Cambridge, MA: Harvard University Press.

— I998b. 'Some Issues in Aristotle's Moral Psychology.' In Mind, Value, and Reality, pp. 23-49. Cambridge, MA: Harvard University Press.

— I998c. 'Values and Secondary Qualities.' In Mind, Value, and Reality, pp. I3 I-50. Cambridge, MA: Harvard University Press.

— I998d. 'Two Sorts of Naturalism.' In Mind, Value, and Reality, pp. I67-97. Cambridge, MA: Harvard University Press.

- 2009a. 'On Pippin's Postscript.' In Having the World in View: Essays on Kant, Hegel, and Sellars, pp. I 8 5-203. Cambridge, MA: Harvard University Press.

- 2009b. 'Sellars on Perceptual Experience.' In Having the World in View: Essays on Kant, Hegel, and Sellars, pp. 3-22. Cambridge, MA: Harvard University Press.

- 2009c. 'Why Is Sellars' Essay Called 'Empiricism and the Philosophy of Mind'?' In Having the World in View: Essays on Kant, Hegel, and Sellars, pp. 22 I-38. Cambridge, MA: Harvard University Press.

Medina, J. 2013. The Epistemology of Resistance: Gender and Racial Oppression, Epistemic Injustice, and Resistant Imaginations. Oxford: Oxford University Press.

Mills, C. I997. The Racial Contract. Ithaca, NY: Cornell University Press.

— I998. 'Alternative Epistemologies.' In Blackness Visible: Essays on Philosophy and Race, pp. 2I-40. Ithaca, NY: Cornell University Press.

- 2007. 'White Ignorance.' In S. Sullivan \& N. Tuana (eds), Race and Epistemologies of Ignorance, pp. I I-38. Albany, NY: State University of New York Press.

Pippin, R. 2005. 'Postscript: On McDowell's Response to 'Leaving Nature Behind'.' In The Persistence of Subjectivity: On the Kantian Aftermath, pp. 206-20. Cambridge: Cambridge University Press.

Pohlhaus, G. 20I2. 'Relational Knowing and Epistemic Injustice: Toward a Theory of Willful Hermeneutical Injustice.' Hypatia, 27: 7 I 5-35.

Railton, P. I997. 'Moral Realism.' In S. Darwall, A. Gibbard \& P. Railton (eds), Moral Discourse and Practice: Some Philosophical Approaches, pp. I37-63. Oxford: Oxford University Press.

Sellars, W. I997. Empiricism and the Philosophy of Mind. Cambridge, MA: Harvard University Press.

Spelman, E. 2007. 'Managing Ignorance.' In S. Sullivan \& N. Tuana (eds), Race and Epistemologies of Ignorance, pp. I I9-3 I. Albany, NY: State University of New York Press.

Sullivan S. and Tuana N. (eds) 2007. Race and Epistemologies of Ignorance. Albany, NY: State University of New York Press.

Taylor, C. I98 5a. 'What Is Human Agency?' In Human Agency and Language: Philosophical Papers I, pp. I 5-44. Cambridge: Cambridge University Press. 
- 1985b. 'Language and Human Nature.' In Human Agency and Language: Philosophical Papers I, pp. 2I4-47. Cambridge: Cambridge University Press.

Thompson, M. 2008. 'The Representation of Life.' In Life and Action: Elementary Structures of Practice and Practical Thought, pp. 25-82. Cambridge, MA: Harvard University Press.

Matthew Congdon is a Senior Lecturer in the Department of Philosophy at Vanderbilt University. He received his PhD from the New School for Social Research in 20I4. His research focuses on ethics and social philosophy. He is currently completing a book project titled Moral Articulation, which explores the process of moral concept formation by looking at the development of historically unprecedented moral terms. 